\title{
"A Comparative Study of Impact Education, State and Gender on Adjustment of Adolescent School Going Tribal Students in Rajasthan and Gujarat.
}

\author{
Rashi Mathur, Dr. Shobha Golwarkar \\ (Research Scholar) Mewar University, Gangrar.
}

\begin{abstract}
This paper is an attempt to study the impact of Education, State and Gender on Adjustment among the adolescent tribal students of Rajasthan \& Gujarat. A sample of 600, Tribal students of Rajasthan \& Gujarat States are taken for this work. The tribal students are divided into higher educated group (class- IX to XII) and lower educated group ( class-VI to VIII).The Adjustment of school going students are analyzed by the administration of the Adjustment Inventory for School Students(AISS) by Sinha \& Singh. In both states the tribally dominated schools are selected. The results are analyzed by Mean, S.D, $t$-test \& ANNOVA
\end{abstract}

\section{Introduction}

Adjustment is an adaptive process, which includes relation to a variety of demands or pressures upon an individual. So, different people will deal similar situations demanding adjustment differently. Coleman (1960) explained that effective adjustment means that an individual copes with the problem in such a way so as to maintain his integrity and well being.

Carter V. Good States that -"Adjustment is the process of finding and adopting modes of behavior suitable to the environment or change in the environment. The favorable, neutral and unfavorable adaptation of an organism to external and internal stimulation and the process by which individual or groups accept, compromise with or acquire with social forces or one another".

Benard defined Adjustment as "Adjustment is the ability to select appropriate and effective measures to meet the demands of environment while maintaining a healthy attitude toward the circumstance".

From the above definitions, A person is said to be adjusted when he is relatively happy, efficient and has some degree of social feelings. In simple word adjustment is an all inclusive term meaning relationship between an individual and his environment through which his needs are satisfied in accordance with social demands .In this piece of work the researcher wants to see Adjustment among the tribal students of Rajasthan \& Gujarat states

So, the statement of the problem is,

\section{Hypotheses}

Following hypotheses were formulated:

* There is no significant relationship on the Impact of Education, on Adjustment of adolescent

( Higher Educated and Lower Educated) school going tribal students of Rajasthan and Gujarat.

* There is no significant relationship on the Impact of State on Adjustment of adolescent

( Higher Educated and Lower Educated) school going tribal students of Rajasthan and Gujarat.

* There is no significant relationship on the Impact of Gender on Adjustment of adolescent

( Higher Educated and Lower Educated) school going tribal students of Rajasthan and Gujarat.

\section{Methodology}

In present piece of work the researcher wants to study, "The Impact of Education, State and Gender on Adjustment of Adolescent school going Tribal students in Rajasthan and Gujarat". As we know that Rajasthan is one of the major state in the country where concentration of tribal population is high. The dominating tribes of the state are Mina, Bhil, Garasia, Damor and Sahariya. The Tribal areas of Rajasthan is divided in four important geographical zones- 
Zone 1-Consists of the southern districts of Rajasthan mainly Banswara, Dungarpur, Udaipur and Cittorgarh. This zone is mostly inhabited by Bhils. Besides Samilwara Block of Dungarpur district, which is inhabited by Garasia tribe.

Zone 2- Consists of Sirohi, Sikar district, which is inhabited by Garasia tribe.

Zone 3- comprising of Jaipur, Sikar and Alwar district, which is inhabited by Mina tribe

Zone 4- is consisting of Tonk, Bundi, Kota, Jahalawar, Swai Madhopur districts which was a mixed population of Bhils and Mina. The Kishanganj and Shaddab tehsils of Baran district are inhabited mainly by Shahriyas.

The researcher has taken the Zone 1 for survey because this zone is having its boundaries with the neighbor state Gujarat.

Sample

In this work the data were collected from a sample of 600 Tribal adolescent school going students of Rajasthan and Gujarat state. The random sampling method was used. The adolescent groups included both girls and boys of age group 12 to 16 years old and the classes varies from VI to XII. The group was divided as higher educated ( class IX to XII) and lower educated(class VI to VIII)

Tool used:

On the Basis of above reason investigator has chose adjustment inventory for school student by Dr. A.K.P. Sinha and Dr. R. P. Singh

\section{Description of the tool}

This test contains three main components, which are as follows.

$>$ Emotional

$>$ Social and

$>$ Educational

Meaning of the symbols and explanation of the areas:

(i) Emotional Adjustment : High score indicate unstable emotion. Students with low scores tend to be emotionally stable.

(ii) Social Adjustment : Individuals scoring high are submissive and retiring low scores indicate aggressive behavior.

(iii) Educational Adjustment : Individuals scoring high are poorly adjusted with their curricular and cocurricular programs. Persons with low scores are interested in school programs.

The inventory consisted of 60 items, 20 items in each area of adjustment.

\section{Procedure followed to score the response:}

As mentioned above, the questionnaire contains 60 items. For each item, five point rating scale was

used,

$\begin{array}{llc}\text { Strongly agree } & - & 5 \text { marks } \\ \text { Agree } & - & 4 \text { marks } \\ \text { Undecided } & - & 3 \text { marks } \\ \text { Disagree } & - & 2 \text { marks } \\ \text { Strongly disagree } & - & 1 \text { marks }\end{array}$

For positive statement, the respondent who answer "Strongly agree" got five marks, "Agree" got four marks, "Undecided" got three marks, "Disagree" got two marks and Strongly disagree got one marks.

The questionnaire was filled by the students as the given to the students and instructions were given while attempting the items. The filled questionnaire were obtained back for scoring and analysis of data.

\section{Statistics Used:}

Statistical measures such as Mean, S.D t-test\& ANNOVA were used to interpret the obtained data.

\section{Analysis and Interpretation of data (Independent variables \& dependent variables) of Standardized Adjustment questionnaire}

The data were analyzed and tabulated by using ANNOVA the following results are obtained on Independent variables- Education, State, Gender and Dependent variables of Adjustment questionnaire were Educational, Social and Emotional.

The below tables show the Impact of Education, State \& Gender on the Adjustment of adolescent tribal school going students of Rajasthan \& Gujarat. The adjustment includes Educational, Social \& Emotional. 
Table:1 Comparison of Education, State, Gender on the dependent Variable Educational.

Dependent Variable:Educational

\begin{tabular}{|l|l|l|l|l|l|}
\hline Source & Sum of Squares & df & Mean Square & F & Sig. \\
\hline EDUCATION & 5997.682 & 1 & 5997.682 & 388.152 & .000 \\
STATE & 327.082 & 1 & 327.082 & 21.168 & .000 \\
GENDER & 945.015 & 1 & 945.015 & 61.159 & .000 \\
EDUCATION * STATE & 950.042 & 1 & 950.042 & 61.484 & .000 \\
EDUCATION * GENDER & 51.042 & 1 & 51.042 & 3.303 & .070 \\
STATE * GENDER & 33.135 & 1 & 33.135 & 2.144 & .144 \\
EDUCATION * STATE * GENDER & 157.082 & 1 & 157.082 & 10.166 & .002 \\
Error & 9147.520 & 592 & 15.452 & & \\
Corrected Total & 17608.598 & 599 & & & \\
\hline
\end{tabular}

The above table indicates that there is a significant impact of Education on (Higher/ Lower group) on the Educational aspect of Adjustment . While the similar impact of State (Rajasthan \&Gujarat) and the impact of gender

(Boys /girls ) is found to be significant. The interaction effect of education \& State, Education \& Gender but State \& Gender are found to be non significant. The table further reflects that the interaction effects of all three independent variables

( Education, State \& Gender) is found to be non significant. It infers that there is a significant difference between higher educated and lower educated students on adjustment of educational aspect. It further reflects that there is significant effect of State and gender on the Educational aspect.

Table:2 Comparison of Education, State, Gender on the dependent Variable Social.

Dependent Variable:Social

\begin{tabular}{|l|l|l|l|l|l|}
\hline Source & Sum of Squares & df & Mean Square & F & Sig. \\
\hline EDUCATION & 5691.840 & 1 & 5691.840 & 361.783 & .000 \\
STATE & 443.760 & 1 & 443.760 & 28.206 & .000 \\
GENDER & 878.460 & 1 & 878.460 & 55.836 & .000 \\
EDUCATION * STATE & 917.607 & 1 & 917.607 & 58.325 & .000 \\
EDUCATION * GENDER & 20.907 & 1 & 20.907 & 1.329 & .249 \\
STATE * GENDER & 7.707 & 1 & 7.707 & .490 & .484 \\
EDUCATION * STATE & $* 152.007$ & 1 & 152.007 & 9.662 & .002 \\
GENDER & & & & & \\
Error & 9313.787 & 592 & 15.733 & & \\
Corrected Total & 17426.073 & 599 & & & \\
\hline
\end{tabular}

The above table indicates that there is a significant impact of Education on (Higher/ Lower group) on the Social aspect of Adjustment . While the similar impact of State (Rajasthan \&Gujarat) and the impact of gender (Boys /girls ) is found to be significant. The interaction effect of education \& State, Education \& Gender but State \& Gender are found to be non significant. The table further reflects that the interaction effects of all three independent variables ( Education, State \& Gender) is found to be non significant. It infers that there is a significant difference between higher educated and lower educated students on adjustment of Social aspect. It further reflects that there is significant effect of State and gender on the Social aspect. 
Table:3 Comparison of Education, State, Gender on the dependent Variable Emotional Dependent Variable:Emotional

\begin{tabular}{|l|l|l|l|l|l|}
\hline Source & $\begin{array}{l}\text { Sum of } \\
\text { Squares }\end{array}$ & df & $\begin{array}{l}\text { Mean } \\
\text { Square }\end{array}$ & F & Sig. \\
\hline EDUCATION & 5563.215 & 1 & 5563.215 & 336.122 & .000 \\
STATE & 469.935 & 1 & 469.935 & 28.393 & .000 \\
GENDER & 885.735 & 1 & 885.735 & 53.515 & .000 \\
EDUCATION * STATE & 910.202 & 1 & 910.202 & 54.993 & .000 \\
EDUCATION * & 23.602 & 1 & 23.602 & 1.426 & .233 \\
GENDER & 7.482 & 1 & 7.482 & .452 & .502 \\
STATE * GENDER & 159.135 & 1 & 159.135 & 9.615 & .002 \\
EDUCATION * STATE & & & & & \\
* GENDER & 9798.293 & 59 & 16.551 & & \\
Error & 17817.598 & 59 & & & \\
Corrected Total & 59 & & & \\
\hline
\end{tabular}

The above table indicates that there is a significant impact of Education on (Higher/ Lower group) on the Emotional aspect of Adjustment .While the similar impact of State (Rajasthan \&Gujarat) and the impact of gender (Boys /girls ) is found to be significant. The interaction effect of education \& State, Education \& Gender but State \& Gender are found to be non significant. The table further reflects that the interaction effects of all three independent variables (Education, State \& Gender) is found to be non significant. It infers that there is a significant difference between higher educated and lower educated students on adjustment of Emotional aspect. It further reflects that there is significant effect of State and Gender on the Emotional aspect.

Table :4 Comparison of Total Adjustment on Education, State, Gender.

Dependent Variable: Total Adjustment

\begin{tabular}{|l|l|l|l|l|l|}
\hline Source & $\begin{array}{l}\text { Sum of } \\
\text { Squares }\end{array}$ & df & $\begin{array}{l}\text { Mean } \\
\text { Square }\end{array}$ & F & Sig. \\
\hline EDUCATION & 51745.307 & 1 & 51745.307 & 816.408 & .000 \\
STATE & 3700.167 & 1 & 3700.167 & 58.379 & .000 \\
GENDER & 937.500 & 1 & 937.500 & 14.791 & .000 \\
EDUCATION * STATE & 8332.827 & 1 & 8332.827 & 131.471 & .000 \\
EDUCATION * & 47.040 & 1 & 47.040 & .742 & .389 \\
GENDER & & & & & \\
STATE * GENDER & 33.607 & 1 & 33.607 & .530 & .467 \\
EDUCATION * STATE & 150.000 & 1 & 150.000 & 2.367 & .124 \\
* GENDER & & & & & \\
Error & 37521.947 & 592 & 63.382 & & \\
Corrected Total & 102468.393 & 599 & & & \\
\hline
\end{tabular}

The above table indicates that there is a significant impact of Education, State and Gender of Higher and Lower group on the Adjustment( Educational, Social and emotional) .While the similar impact of Education and State (Rajasthan \&Gujarat) on the adjustment but the impact of gender (Boys /girls ) and education is found to be non significant. The interaction effect of gender State, Education are found to be non significant. The table further reflects that the interaction effects of all three independent variables (Education, State \& Gender) is found to be non significant. It infers that there is a non significant difference between higher educated and lower educated students on adjustment.

Findings: 1. The impact of Education, State \& Gender on the dependent variable Educational of the Adjustment questionnaire is found to be significant at 0.01 level which infer that there is no significant impact of Education, State \& Gender on the Educational variable of the adjustment. But as we compare Education \& State, Education \& Gender \& State \& Gender, there is no significant at 0.01 level, which depicts that there was a significant difference on the educational variable. 
2. The Social aspect of the adjustment questionnaire infers that there is a non significant difference on the Education, State \& Gender but as compared to Education \& Gender, State \& Gender there was a significant difference on the Social Variable of the higher educated \& the lower educated group of the both States which infer that the higher educated students are highly socially adjusted as compared to the lower educated students.

3. The dependent variable emotional of the adjustment questionnaire infer that there is a non significant difference on the Education, State \& Gender but as compared to Education \& Gender, State \& Gender there was a significant difference on the Emotional Variable of the higher educated \& the lower educated group of the both States which infer that the higher educated students are highly Emotionally adjusted as compared to the lower educated students.

\section{Conclusion}

From the above findings it can be concluded that the impact of education on adjustment (educational, social \& emotional) is found to be non significant in both states( Rajasthan \& Gujarat), which infer that there is no significant difference between higher \& lower group, but as we compare Education \& Gender, State \& Gender there was a significant difference on adjustment(educational, social \& emotional), which infer that the higher educated students are highly adjusted as compared to the lower educated students.

\section{Refernces}

[1]. Bansal,I.P: A study of the adjustment difference among scheduled caste and high caste adolescents. Educational and Psychological Research Journal, 1(1),39-41

[2]. Verma, M.: Factors affecting academic achievement: A cross cultural study of tribal and non tribal students at junior high school level in Uttar Pradesh.

[3]. Ushasri.S : Social disadvantage, academic adjustment and scholastic achievement. Social change: Journal of the council for social development, 10,23-30.

[4]. Metha, Manju; A comparative study of SC,ST \& non backward class higher secondary boys on adjustment pattern and academic achievement: Journal on Tribe, 144-151. 